\title{
LINTASAN SEJARAH FILSAFAT PENDIDIKAN PERENIALISME DAN AKTUALISASINYA
}

\author{
Musa Pelu*
}

\begin{abstract}
Abstrak
Antara filsafat dan pendidikan terdapat kaitan yang erat. Filsafat memiliki aspek-aspek utama yang dapat dijadikan landasan bagi pendidikan. Aspek-aspek yang dimaksud adalah aspek-aspek metafisis, epistemologis, dan aksiologis. Aspek metafisis antara lain berkaitan dengan persoalan realitas yang tercermin pada bahan ajar, pengalaman dan keterampilan. Aspek epistemologis berkaitan dengan persoalan pengetahuan dan kebenaran, termasuk di dalamnya sumber belajar dan metode pembelajaran. Aspek aksiologis berkaitan dengan nilai kebaikan dan keindahan yang akan ditanamkan kepada peserta didik. Perenialisme sebagai aliran dalam filsafat juga memiliki ketiga aspek tersebut yang dapat dijadikan landasan bagi pendidikan yang mendasarkan pada filsafat ini.
\end{abstract}

\section{Kata kunci : Filsafat Perenialisme, Pendidikan}

\section{Pendahuluan}

Perenialisme merupakan suatu aliran dalam pendidikan yang lahir pada abad kedua puluh. Perenialisme berasal dari kata perennial yang berarti abadi, kekal, selalu atau terus tiada akhir. Pengertian ini dapat dianalogikan dengan bunga yang terus-menerus mekar dari musim ke musim. Hal ini menunjukkan adanya gejala yang terus ada dan sama. Apabila gejala dari musim ke musim ini dihubungkan satu sama lain seolah-olah merupakan benang dengan corak warna yang khas, yaitu terus menerus sama.

Berdasarkan pandangan tersebut, maka untuk proses sivilisasi atau pembudayaan perlu diteliti tentang adanya watak yang selalu berulang kembali dan sama.

\footnotetext{
* Musa Pelu adalah Dosen Pendidikan Sejarah Universitas Sebelas Maret Surakarta Jl. Ir. Sutami 36 A Surakarta.
} 
Tanpa usaha semacam itu, manusia akan kehilangan jejak dan faktor-faktor yang menstabilkan peradaban sendiri. Benang dengan warna yang khas yang terus menerus ada ini, harus dicari dalam lingkup filsafat dengan melihatnya dari aspek metafisika, epistomologi, aksiologi, dan logika. Filsafat perenialisme berusaha untuk menjawabnya agar dapat menstabilkan peradaban itu sendiri.

Berdasarkan pandangan di atas, maka perenialisme menentang pandangan progresivisme yang menekankan perubahan dan sesuatu yang baru. Jalan yang ditempuh oleh kaum perenialis adalah dengan jalan mundur ke belakang, dengan menggunakan kembali nilai-nilai atau prinsip prinsip umum yang telah menjadi pandangan hidup yang kuat, kukuh pada zaman kuno dan abad pertengahan.

Perenialisme memandang bahwa keadaan sekarang sebagai zaman yang mempunyai kebudayaan yang terganggu oleh kekacauan, kebingungan, dan kesimpangsiuran. Oleh karena itu, dinilai sebagai zaman yang membutuhkan usaha untuk mengamankan lapangan moral, intelektual dan lingkungan sosial kultural yang lain.

Perenialisme mengambil jalan yang regresif karena berpandangan bahwa tidak ada jalan lain kecuali kembali kepada prinsip umum yang telah menjadi dasar tingkah laku dan perbuatan Zaman Kuno dan Abad Pertengahan, yaitu kepercayaankepercayaan aksiomatis mengenai pengetahuan, realita dan nilai. Pandangan perenialisme dengan mengambil jalan regresif tersebut, bukanlah hanya nostalgia atau rindu akan nilai-nilai lama untuk diingat atau dipuja, tetapi berpendapat bahwa nilai-nilai tersebut mempunyai kedudukan vital bagi pembangunan kebudayaan abad ke duapuluh. Prinsip-prinsip aksiomatis yang tidak terikat oleh waktu itu terkandung dalam semua sejarah.

Perenialisme merupakan filsafat yang susunan dirinya merupakan kesatuan. Oleh karena itu, premispremis yang disusun merupakan hasil pikiran yang memberi kemungkinan bagi seseorang untuk bersikap yang tegas dan lurus. Sehingga tidak sejalan dengan prinsip-prinsip yang evolusionistis dan naturalistis.

\section{Tokoh-Tokoh Perenialisme}

Perenialisme berpendapat bahwa tokoh-tokoh yang mampu membawa perbaikan terhadap keadaan sekarang yang dianggap mempunyai kebudayaan yang terganggu oleh kekacauan, kebingungan dan kesimpangsiuran adalah Plato, Aristoteles, dan Thomas Aquinas. Ketiga tokoh tersebut dianggap memiliki pendirian dan pandanganpandangan yang masih mempunyai arti bagi abad ini. Di samping itu, pendirian dan pandangan-pandangan itu masih dapat dipertimbangkan sebagai dasar pedoman kebudayaan abad ini.

\section{Plato (427-347 SM)}

Plato adalah seorang filsuf idealis yang memandang dunia ide sebagai dunia kenyataan. Ide adalah realitas. 
Oleh karena itu, filsafat Plato dipandang beraliran realistis. Dalam tulisannya "Republik" Plato menyatakan keyakinannya bahwa jalan untuk membentuk masyarakat menjadi stabil adalah menentukan kedudukan yang pasti bagi setiap orang atau setiap kelas menurut kapasitasnya masing-masing dalam masyarakat sebagai keseluruhan. Mereka yang memiliki kebajikan dan kebijaksanaan yang cukup dapat menduduki posisi yang tinggi, dan seterusnya ke bawah bagi mereka yang mempunyai kualitas yang lebih rendah. Dari atas ke bawah mengambil urut-urutan para raja, filsuf, perwira dan prajurit, pekerja tangan dan budak. Yang paling atas adalah mereka yang telah bertahun-tahun mengalami pendidikan dan latihan, dan telah menunjukkan sifat superioritasnya dalam melawan berbagai godaan, serta dapat menunjukkan cara hidup menurut kebenaran tertinggi.

Mengenai standar kebenaran tertinggi, dinyatakan oleh Plato dengan doktrinnya yang disebut Ide. Dunia ini tetap dan satu jenisnya, sedangkan ide tertinggi adalah kebaikan. Tugas ide adalah memimpin budi manusia dan menjadi contoh dunia pengalaman. Dunia ide berbeda dengan dunia pengalaman, yang penangkapannya dilakukan oleh indera. Dunia ide adalah tetap sedangkan dunia pengalaman adalah berubah-ubah. Dunia pengalaman disebut juga dunia bayang-bayang.

Sekali manusia mengenal dan menguasai dunia ide, ia dapat mengetahui jalan yang pasti. Dengan demikian dapat menggunakan sebagai alat untuk mengukur, mengadakan klasifikasi dan penilaian terhadap segala sesuatu yang dialami seharihari.

\section{Aristoteles (483-322 SM)}

Aristoteles adalah murid Plato, tetapi ia tidak setuju dengan pandangan dualistis dari gurunya mengenai dunia, yaitu dunia ide dan dunia bayang-bayang. Untuk itu diciptakanlah teori hilomorfisme, yaitu suatu teori bentuk dalam unsurunsur, gagasan dalam bendabendanya atau jiwa dalam badan.

Menurut Aristoteles, dunia adalah tunggal, merupakan suatu kesatuan dalam tata kosmis. Untuk itu, ia mengemukakan teori yang bersendikan atas gambar piramida yang disebut piramida ontologis Aristoteles. Bagian bawah piramida, terutama di bagian dasarnya terdapat pernyataan yang berujud unsur (matter) dengan bentuk yang paling kecil di antara semua yang berbentuk. Keadaan ini berubah bila kenyataan itu menanjak dari bagian bawah melalui sisi-sisinya hingga sampai pada tingkat yang paling tinggi.

Puncak ini bebas dari sifat-sifat kotor dan pengalaman yang fana, dan disebut penggerak yang tiada gerak, yang mempunyai sifat-sifat ketuhanan. Secara terus menerus puncak ini menarik dan meningkatkan hal-hal atau bendabenda yang lebih rendah ke arahnya. Dengan demikian, tendensi dari kenyataan itu adalah menuju arah aktualitas, sehingga makin lama makin jauh dari potensialitasnya. Apabila dihubungkan dengan manusia, maka manusia itu setiap waktu adalah potensialitas yang 
sedang berubah menjadi aktualitas. Sebagai contoh, meskipun manusia dalam hidupnya tidak jarang pula berkat dimilikinya akal, perasaan, dan kemauannya, semua ini dapat dikurangi. Hal-hal yang bersifat partikular yang merintangi kehidupan dapat diatasi. Melalui peningkatan suasana hidup spiritual ini manusia dapat semakin mendekatkan diri kepada Gerak yang Tanpa Gerak sebagai tujuan dan bentuk terakhir dari segalanya.

\section{Thomas Aquinas (1225-1274)}

Thomas Aquinas mengembangkan ajaran (aliran) yang disebut dengan Thomisme. Menurut ajaran ini, dilihat dari aspek ontologi, dikatakan bahwa Tuhan adalah pencipta segala sesuatu di dunia ini. Tuhan adalah maha baik dan segala sesuatu yang menyertai-Nya adalah baik pula sehingga tidak tepat apabila di dunia ini diadakan pembedaan mana yang baik dan mana yang buruk. Yang perlu ada perbedaan adalah sebagai berikut: "ada makhluk ada yang diadakan, sedangkan adanya Tuhan itu ada dengan sendirinya. Secara filosofis bahwa ada Tuhan adalah esensinya, sedangkan ada makhluk tidak sama dengan esensinya. Ada makhluk memang tidak terpisahkan dari esensinya, tetapi dapat dibedakan satu sama lain, sedangkan pada Tuhan keduanya identik.

Mengenai pandangan tentang dualisme dari Plato, Thomas Aquinas mempunyai pendapat yang berbeda. Menurutnya, pengetahuan itu pada awalnya merupakan persentuhan dunia luar dengan badan (indera), dan ini masih merupakan bahan. Budi lalu mengolah bahan itu menjadi pengetahuan. Bila belum diolah oleh budi dapat juga disebut pengetahuan, tetapi yang baru mempunyai sifatsifat jasmaniah belaka. Budi adalah kemampuan manusia yang tinggi, yang mempunyai cita-cita untuk menuju ke kebenaran sejati yang bersumber pada Tuhan.

Selain budi, manusia juga mempunyai kehendak. Baik budi maupun kehendak selalu menuju kepada Tuhan. Dengan demikian, semakin besar arah budi dan kehendak manusia kepada semuanya, berarti semakin besar pula partisipasi manusia di dunia menurut kehendak Tuhan. Dari penjelasan di atas, maka manusia perlu mempunyai dua jenis kepercayaan, yaitu yang berdasarkan wahyu dari Tuhan dan yang bersifat rasional. Keduanya diperlukan bagi pembinaan individu dan siviliasi, karena saling menyempurnakan. Sebagai contoh, dalam ranah kesusilaan, manusia dapat menyusun hukum-hukum kesusilaan, tetapi hukum itu baru dapat dianggap sempurna bila dilingkungi oleh hukum-hukum supernatural.

Setelah perenialisme menjadi terdesak karena perkembangan politik industri yang cukup berat timbulah usaha untuk bangkit kembali, dan perenialisme berharap agar manusia kini dapat memahami ide dan cita filsafatnya yang menganggap filsafat sebagai suatu azas yang komprehensif perenialisme dalam makna filsafat sebagai satu pandangan hidup yang berdasarkan pada sumber kebudayaan dan hasilhasilnya. 


\section{Pandangan Mengenai Realita}

Perenialisme berpendapat bahwa apa yang dibutuhkan manusia terutama ialah jaminan bahwa "reality is universal that is every where and at every moment the same". Realita itu bersifat universal yang ada di mana saja dan sama di setiap waktu. Dengan keputusan yang bersifat ontologisme, kita akan sampai pada pengertian-pengertian yang hakiki. Ontologi perenialisme berisikan pengertian: benda individual, esensi, aksiden dan substansi.

1. Benda individual adalah benda yang sebagaimana Nampak di hadapan manusia yang dapat ditangkap oleh indera kita, seperti kayu, batu, orang dan lain sebagainya.

2. Esensi dari sesuatu adalah kualitas yang menjadikan atau menyebabkan benda itu lebih intrinsik daripada halnya, misalnya manusia ditinjau dari esensinya adalah makhluk berpikir. Esensi adalah lebih penting daripada halnya.

3. Aksiden adalah keadaan-keadaan khusus yang dapat berubah-ubah dan sifatnya kurang penting dibandingkan dengan esensialnya, misalnya orang suka barang-barang antik, suka berpakaian bagus.

4. Substansi adalah suatu kesatuan dari tiap-tiap yang berpasangan pada setiap individu dari yang khas dan yang universal, yang material dan yang spiritual. Akallah yang harus mengadakan pembedaan mengenai sifat-sifat tersebut.

Disamping yang telah diuraikan di atas, perenialisme memandang bahwa realita itu bersifat teleologis yang mengandung suatu tujuan. Oleh karena semua hal itu bersumber pada kenyataan yang bersifat spiritual, maka tiap-tiap hal itu atau benda melewati jalannya sendiri-sendiri yang tidak dapat dihindari.

Ada empat macam sebab (kausa) yang menjadi pendukung atau pendorong terjadi atau berlangsungnya sesuatu, yaitu sebagai berikut.

a) Kausa materialis, yaitu bahan yang menjadi susunan sesuatu benda, misalnya telor, tepung, dan gula untuk roti.

b) Kausa formalis, yaitu bentuk atau model sesuatu benda, misalnya bulat, panjang, dan lain sebagainya.

c) Kausa efisien, yaitu gerakan yang digunakan dalam pembuatan sesuatu, misalnya cepat, lambat, tergesa-gesa dan lain sebagainya.

d) Kausa finalis, yaitu tujuan atau akhir dari sesuatu benda, misalnya tujuan pembuatan patung.

\section{Pandangan Mengenai Pengetahuan}

Kepercayaan adalah pangkal tolak perenialisme mengenai kenyataan dan pengetahuan. Artinya kebenaran adalah sesuatu yang menunjukkan kesesuaian antara pikir (kepercayaan) dengan benda-benda. Sedang yang dimaksud benda adalah hal-hal yang adanya bersendikan atas prinsip-prinsip keabadian. Oleh karena itu, menurut perenialisme perlu adanya dalil-dalil yang logis, nalar, sehingga sulit untuk diubah atau ditolak kebenarannya. Menurut Aristoteles, prinsip-prinsip itu dapat dirinci menjadi : 
1. Principium identitatis atau hukum identitas, yaitu identitas sesuatu. Misalnya apabila si Ali adalah benarbenar si Ali, maka ia tidak akan menjadi si Budi.

2. Principium contradictionis atau hukum kontradiksi (berlawanan), artinya suatu pernyataan pasti tidak mengandung sekaligus kebenaran dan kesalahan, pasti hanya mengandung satu kenyataan yakni benar atau salah.

3. Principium exclusi terti artinya tidak ada kemungkinan ketiga. Apabila pernyataan pertama salah, pasti pernyataan kedua benar, dan sebaliknya apabila pernyataan pertama benar, pasti pernyataan yang berikutnya tidak benar.

4. Principium rationis suffecientis, artinya apabila sesuatu dapat diketahui asal muasalnya, pasti dapat dicari pula tujuan atau akibatnya.

Ajaran lain dari Aristoteles yang dapat dijadikan pegangan adalah logika. Logika Aristoteles terdiri dari dua hal, yaitu jalan pikiran (rationorum) dan bukti. Jalan pikiran adalah silogisme. Silogisme menunjukkan adanya hubungan logis antara premis mayor, premis minor dan konklusio (kesimpulan). Masingmasing terdiri dari putusan. Setiap putusan terdiri dari pengertian yang berhubungan satu sama lain. Misalnya, kalau kita menerima premis bahwa manusia itu adalah animal rasionale dan kita akui bahwa si Fulan adalah manusia, maka dapat ditarik kesimpulan bahwa si Fulan adalah animal rasionale.

Selain dengan cara deduktif seperti di atas, manusia perlu mengenal dunia dengan cara kebalikannya, yaitu induktif. Cara ini memulai pengenalan dengan hal-hal partikular. Intinya, jika belum mengandung halhal yang universal adalah mustahil data partikular itu dapat membangun kesimpulan-kesimpulan yang universal.

Perenialisme juga mengemukakan adanya hubungan antara ilmu pengetahuan dengan filsafat.

\section{a) Science sebagai ilmu penge- tahuan}

Science yang meliputi biologi, fisika, sosiologi, dan sebagainya ialah pengetahuan yang disebut sebagai empiriological analysis, yakni analisa atas individual things dan peristiwaperistiwa pada tingkat pengalaman dan bersifat alamiah. Science seperti ini dalam pelaksanaan analisa dan penelitiannya mempergunakan metode induktif. Selain itu juga menggunakan metode deduktif, tetapi pusat kajiannya adalah meneliti dan mencoba dengan data tertentu yang bersifat khusus.

\section{b) Filsafat sebagai pengetahuan}

Menurut perenialisme, fisafat yang tertinggi ialah ilmu metafisika. Sebab, science dengan metode induktif bersifat analisa empiris; kebenarannya terbatas, relatif atau kebenarannya probability. Tetapi filsafat dengan metode deduktif bersifat ontological analysis, kebenaran yang dihasilkannya universal, hakiki, dan berjalan dengan hukum-hukum berpikir sendiri, berpangkal pada hukum pertama; bahwa kesimpulannya bersifat mutlak, asasi. 
Hubungan filsafat dan pengetahuan tetap diakui urgensinya, sebab analisa empiris dan analisa ontologi keduanya dianggap perenialisme dapat komplementatif. Tetapi filsafat tetap dapat berdiri sendiri dan ditentukan oleh hukum hukum dalam filsafat sendiri, tanpa tergantung kepada ilmu pengetahuan.

\section{Pandangan Mengenai Nilai}

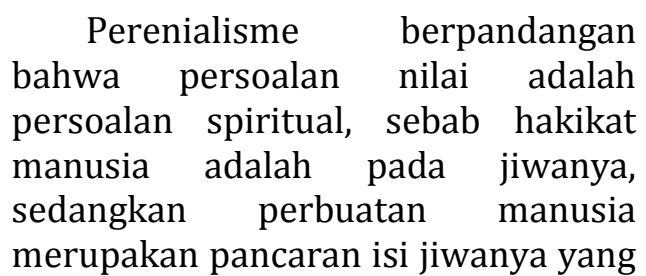
berasal dari dan dipimpin oleh Tuhan.

Secara teologis, manusia perlu mencapai kebaikan tertinggi, yaitu nilai yang merupakan suatu kesatuan dengan Tuhan. Untuk dapat sampai kesana manusia harus berusaha dengan bantuan akal rationya yang berarti mengandung nilai kepraktisan. Menurut Aristoteles, kebajikan dapat dibedakan: yaitu yang moral dan yang intelektual. Kebajikan moral adalah kebajikan yang merupakan pembentukan kebiasaan, yang merupakan dasar dari kebajikan intelektual. Jadi, kebajikan intelektual dibentuk oleh pendidikan dan pengajaran.

Kebajikan intelektual didasari oleh pertimbangan dan pengawasan akal. Oleh perenialisme, estetika digolongkan kedalam filsafat praktis. Kesenian sebagai salah satu sumber kenikmatan keindahan adalah suatu kebajikan intelektual yang bersifat praktis filosofis. Hal ini berarti bahwa di dalam mempersoalkan masalah keindahan harus berakar pada dasar teologis, ketuhanan.

\section{Aliran Perenialisme Dalam Pendidikan}

\section{Pandangan Tentang Pendidikan}

Teori atau konsep pendidikan perenialisme dilatarbelakangi oleh filsafat-filsafat Plato sebagai Bapak Idealisme Klasik, filsafat Aristoteles sebagai Bapak Realisme Klasik, dan filsafat Thomas Aquina yang mencoba memadukan antara filsafat Aristoteles dengan ajaran Gereja Katolik yang tumbuh pada zamannya.

\section{a. Plato (427-347 SM)}

Plato hidup pada zaman kebudayaan yang sarat dengan ketidakpastian, yaitu fisafat sofisme. Ukuran kebenaran dan ukuran moral menurut sofisme adalah manusia secara pribadi, sehingga pada zaman itu tidak ada kepastian dalam moral dan kebenaran, tergantung pada masing-masing individu. Plato berpandangan bahwa realitas yang hakiki itu tetap tidak berubah karena telah ada pada diri manusia sejak dari asalnya. Menurut Plato, dunia ideal, yang bersumber dari ide mutlak, yaitu Tuhan. Manusia menemukan kebenaran, pengetahuan, dan nilai moral dengan menggunakan akal atau ratio.

Tujuan utama pendidikan adalah membina pemimpin yang sadar akan asas normative dan melaksanakannya dalam semua aspek kehidupan. Masyarakat yang ideal adalah masyarakat adil sejahtera. Manusia 
yang terbaik adalah manusia yang hidup atas dasar prinsip idea mutlak, yaitu suatu prinsip mutlak yang menjadi sumber realitas semesta dan hakikat kebenaran abadi yang transcendental yang membimbing manusia untuk menemukan kriteria moral, politik, dan sosial serta keadilan. Ide mutlak adalah Tuhan.

\section{b. Aristoteles (384-322 SM)}

Aristoteles (384-322 SM) adalah murid Plato, namun dalam pemikirannya mereaksi terhadap filsafat gurunya, yaitu idealisme. Hasil pemikirannya disebut filsafat realisme. Ia mengajarkan cara berpikir atas prinsip realistis, yang lebih dekat pada alam kehidupan manusia sehari-hari.

Menurut Aristoteles, manusia adalah makhluk materi dan rohani sekaligus. Sebagai materi, ia menyadari bahwa manusia dalam hidupnya berada dalam kondisi alam materi dan sosial. Sebagai makhluk rohani, manusia sadar ia akan menuju pada proses yang lebih tinggi yang menuju kepada manusia ideal. Perkembangan budi merupakan titik pusat perhatian pendidikan dengan filsafat sebagai alat mencapainya.

Aristoteles menganggap penting pula pembentukan kebiasaan pada tingkat pendidikan usia muda dalam menanamkan kesadaran menurut aturan moral. Ia juga menganggap kebahagiaan sebagai tujuan dari pendidikan yang baik. Ia mengembangkan individu secara bulat, totalitas. Aspek-aspek jasmaniah, emosi, dan intelek sama dikembangkan, walaupun ia mengakui bahwa kebahagiaan tertinggi ialah kehidupan berpikir.

\section{c. Thomas Aquinas (1225-1274)}

Thomas berpendapat pendidikan adalah menuntun kemampuankemampuan yang masih tidur menjadi aktif atau nyata tergantung pada kesadaran tiap-tiap individu. Seorang guru bertugas untuk menolong membangkitkan potensi yang masih tersembunyi dari anak agar menjadi aktif dan nyata. Menurut J. Maritain, norma fundamental pendidikan adalah: cinta kebenaran, cinta kebaikan dan keadilan, kesederhanaan dan sifat terbuka terhadap eksistensi, cinta kerjasama.

Kaum perenialis juga percaya bahwa dunia alamiah dan hakikat manusia pada dasarnya tetap tidak berubah selama berabad-abad. Gagasan-gagasan besar terus memiliki potensi yang paling besar untuk memecahkan permasalahanpermasalahan di setiap zaman. Selain itu, filsafat perenialis menekankan kemampuan-kemampuan berpikir rasional manusia sehingga membedakan mereka dengan binatangbinatang lain.

\section{Pandangan Tentang Belajar}

Teori dasar dalam belajar menurut perenialisme adalah :

\section{a. Mental disiplin sebagai teori dasar}

Penganut perenialisme sependapat bahwa latihan dan pembinaan berpikir (mental discipline) adalah salah satu kewajiban tertinggi dari belajar, atau keutamaan dalam proses belajar 
(yang tertinggi). Karena itu teori dan program pendidikan pada umumnya dipusatkan kepada pembinaan kemampuan berpikir.

\section{b. Rasionalitas dan Asas Ke- merdekaan}

Asas berpikir dan kemerdekaan harus menjadi tujuan utama pendidikan; otoritas berpikir harus disempurnakan sesempurna mungkin. Dan makna kemerdekaan pendidikan ialah membantu manusia untuk menjadi dirinya sendiri, be him-self, sebagai essential-self yang membedakannya daripada makhlukmakhluk lain. Fungsi belajar harus diabdikan bagi tujuan ini, yaitu aktualitas manusia sebagai makhluk rasional yang dengan itu bersifat merdeka.

\section{c. Learning to Reason ( Belajar untuk Berpikir)}

Perenialisme tetap percaya dengan asas pembentukan kebiasaan dalam permulaan pendidikan anak. Kecakapan membaca, menulis dan berhitung merupakan landasan dasar. Dan berdasarkan pentahapan itu, maka learning to reason menjadi tujuan pendidikan tinggi.

\section{d. Belajar sebagai Persiapan Hidup}

Bagi Thomisme, belajar untuk berpikir dan belajar untuk persiapan hidup (dalam masyarakat) adalah dua langkah pada jalan yang sama, yakni menuju kesempurnaan hidup, kehidupan duniawi menuju kehidupan syurgawi.

\section{e. Learning through Teaching} (Belajar melalui Pengajaran)
Adler membedakan antara learning by instruction dan learning by discovery, penyelidikan tanpa bantuan guru. Dan sebenarnya learning by instruction adalah dasar dan menuju learning by discovery, sebagai self education. Menurut perenialisme, tugas guru bukanlah perantara antara dunia dengan jiwa anak, melainkan guru juga sebagai murid yang mengalami proses belajar sementara mengajar.

Guru mengembangkan potensipotensi self discovery; dan ia melakukan moral authority atas murid-muridnya, karena ia adalah seorang professional yang berkualifikasi dan superior dibandingkan murid.

\section{Pandangan Tentang Kurikulum}

Tugas utama pendidikan adalah mempersiapkan anak didik kearah kematangan. Matang dalam arti hidup akalnya. Untuk itulah, akal perlu mendapat tuntutan kearah kematangan tersebut.

Perenialisme tidak mengesampingkan memorisasi, meskipun memorisasi itu bersifat mekanis, karena belajar mempunyai peranan untuk menerima benih-benih yang baik, maka memorisasi diperlukan. Memorisasi diperlukan agar benihbenih tersebut berada dengan baik dalam jiwa anak didik sebelum dapat berakar dan tumbuh.

Sejalan dengan pandangan di atas, perenialisme sangat menghargai pengalaman yang tidak langsung, tanpa mengesampingkan pengalaman langsung. Pengalaman langsung diperlukan agar mata pelajaran-mata pelajaran yang diterima anak didik 
dapat mencapai integrasi dan untuk mempelajari kebutuhan riil manusia.

Sekolah rendah memberikan pendidikan dan pengetahuan yang serba dasar. Melalui pengetahuan yang tradisional seperti membaca, menulis dan berhitung, anak didik memperoleh dasar penting bagi pengetahuan-pengetahuan yang lain. Selain itu, sekolah dasar juga berfungsi memberikan pendidikan watak dengan menekankan pada kebajikan-kebajikan moral. Untuk itu,diperlukan penanaman dan latihan yang memadau agar proses internalisasi kebajikan tersebut berhasil dengan baik.

Oleh karena pendidikan rendah baru memberikan pendidikan dasar, maka belum dapat dijadikan dasar pembaharuan sosial dalam arti sesungguhnya sehingga belum disebut sebagai badan untuk mengadakan pembaharuan sosial.

Prinsip-prinsip kuriklum untuk sekolah dasar yang telah diuraikan di atas, berlaku pula untuk sekolah menengah dengan suatu prinsip peningkatan pematangan akal anak didik. Peningkatan ini adalah dalam bentuk pendidikan umum, yang menuntun perkembangan umum, psikis dan fisik anak didik yang berumur 12 sampai 20 tahun. Bagi yang berumur 12 sampai 16 tahun, kurikulum yang diperlukan terdiri dari bahasa-bahasa asing kuno, seperti Latin dan Yunani dan bahasabahasa modern. Penguasaan bahasa merupakan dasar untuk pengenalan dunia luas bagi anak didik.

Anak didik yang berumur 16 tahun sampai 20 tahun perlu mendapatkan pengetahuan tentang : a. Aspek penalaran seperti logika, retorika, paramasastera dan ilmu pasti. Pengetahuan ini dapat meningkatkan dan kecerdasan akal.

b. Buku-buku besar sepanjang masa, karangan dari tokoh-tokoh besar, yang karenanya bernilai besar pula sepanjang masa. Materi buku ini merupakan isi hakiki dari kebudayaan.

Mengenai hakikat perguruan tinggi, Robert Hutchkins mengatakan bahwa jika abad pertengahan bersifat teologis, maka masa sekarang seharusnya bersifat filsafat metafisika yang pada dasarnya adalah cinta intelektual Tuhan sehingga perguruan tinggi tidak seyogyanya bersifat utilistis. Perguruan tinggi sekarang perlu menyelenggarakan penelitian sesuai dengan fungsinya masingmasing. Namun hasil penelitian yang bermutu tinggi adalah yang bersendikan filsafat.

\section{Analisis Filsafat Perenialisme dan Aktualisasinya}

Perenialisme memandang bahwa keadaan sekarang sebagai suatu masa dengan kebudayaan yang terganggu atau diliputi dengan kekacauan, kebingungan dan kesimpangsiuran. Untuk itu harus diselamatkan dengan cara kembali kepada prinsip umum yang telah menjadi dasar tingkah laku dan perbuatan Zaman Kuno dan Abad Pertengahan yaitu kepercayaankepercayaan aksiomatis mengenai realita, pengetahuan, dan nilai dari zaman tersebut.

Menurut perenialisme, realita tertinggi berada di balik alam, yaitu 
Tuhan sendiri yang bersifat penuh kedamaian dan supernatural. Tuhan adalah aktualitas murni yang sunyi dan sepi dari substansi. Konsepkonsep dasar ontologi bersendikan atas pengertian-pengertian yang pasti. Seperti benda individual, esensi, aksiden, dan substansi. Pengetahuan dipandang mengandung kebenaran bila dapat memiliki evidensi- diri sendiri. Jalan yang perlu ditempuh akal untuk mencapainya adalah dengan penalaran, baik yang bersifat induktif, deduktif, serta perpaduan keduanya. Sedangkan nilai menurut perenialisme adalah pandangan mengenai hal-hal yang bersifat spiritual. Tuhan adalah sumber nilai dan karenanya nilai selalu bersifat teologis.

Usaha perbaikan keadaan sekarang melalui penerapan kembali nilai-nilai dan kepercayaan aksiomatis yang berdasarkan pada sumber kebenaran dan kestabilan yaitu Tuhan akan memberikan kontribusi yang positif. Nilai-nilai kebaikan dan kebenaran Tuhan yang dianggap bersifat abadi apabila dijadikan way of life bagi penganutnya akan menjadi kontrol atau pedoman bagi individu untuk bersikap dan berperilaku yang baik dan benar. Nilai-nilai dan kepercayaan tersebut sekaligus sebagai dasar pedoman untuk meluruskan kembali atau sebagai bahan instrospeksi diri terhadap kebudayaan masa sekarang melalui pendukung-pendukungnya untuk kembali kepada nilai-nilai dan kebenaran yang bersifat teologis yang abadi.

Tetapi disisi lain pandangan perenialisme tersebut akan berbenturan dengan nilai-nilai dan kepercayaan masyarakat sebagai hasil budaya yang keberadaanya merupakan respon terhadap perubahan, karena tidak ada satu masyarakat yang statis. Nilai-nilai yang dianggap baik dan benar belum tentu baik atau benar untuk masa sekarang berdasarkan fenomena yang terjadi di masyarakat. Perenialisme memandang bahwa kebenaran dan pengetahuan bisa dicapai dengan akal agar memiliki evidensi sendiri. Argumen ini juga di buktikan dengan pandangan Aristoteles sendiri yang nota benenya adalah pendukung perenialisme. Aristoteles mengatakan bahwa yang buat semua orang dikatakan baik, tetapi Aristoteles tidak berhasil menerangkan mengapa sesuatu yang dikatakan baik dapat dianggap tidak baik oleh orang lain.

Aristoteles sulit menjawabnya. Hal ini tidak bisa dilepaskan dari sejarah lahirnya perenialisme itu sendiri. Perenialisme lahir sebagai reaksi terhadap pendidikan progresif. Perenialisme menentang pandangan progresivisme yang menekankan pada perubahan dan sesuatu yang baru. Dalam kehidupan ini, perubahan merupakan suatu keniscayaan karena tidak ada yang tetap kecuali perubahan itu sendiri. Perubahan merupakan bagian yang melekat dalam kehidupan manusia dan niscaya terjadi terus menerus. Perubahan yang dimaksud adalah perubahan dalam berbagai aspek sosial yang berkaitan erat, langsung atau tidak langsung dengan tindakan manusia dalam lingkup lokal dan global yang memberi konteks 
terhadap pemikiran, sikap dan tindakan manusia itu sendiri.

Perubahan sosial diartikan sebagai perubahan yang terkait dengan kehidupan masyarakat, termasuk di dalamnya perubahan sistem nilai dan norma sosial, sistem pelapisan sosial, struktur sosial, proses-proses sosial, pola sikap dan tindakan sosial serta lembaga kemasyarakatan. Dalam hal ini perubahan sikap sudah inheren dalam perubahan sosial. Sebagai contoh, pada masa dulu orang makan sambil berdiri, itu dikatakan tidak baik dan sopan; tetapi pada masa sekarang, dalam pesta baik pernikahan, ulang tahun, syukuran dan sebagainya, para tamu menikmati hidangan pesta dengan berdiri sudah menjadi sebuah kebiasaan. Dan kebanyakan orang mengatakan hal itu baik-baik saja. Kebaikan ini berdasarkan indikator/parameter penilaiannya sudah berubah. Orang sekarang mempertimbangkannya dari segi kepraktisan, efisiensi dan kefektifannya.

Terhadap berbagai persoalan yang terjadi di masyarakat saat ini, sebagai akibat terjadinya perubahan, harus segera diatasi dan diawali dengan menganalisa terhadap segala sesuatu terkait dengan permasalahan itu. Solusinya tidak harus kembali kepada nilai-nilai dan kepercayaan yang diyakini pada zaman kuno dan abad pertengahan. Namun demikian, sebagai contoh fenomena yang bisa menggambarkan penerapan filsafat perenialisme tetapi dalam konteks sekarang dapat dideskripsikan sebagai berikut.
1. Peristiwa kerusuhan yang terjadi pada tanggal 13-15 Mei 1998 adalah yang kesebelas kalinya menimpa Kota Surakarta. Dalam peristiwa itu terjadi aksi kerusuhan, penjarahan, pengrusakkan, pembakaran, pemerkosaan, yang hampir seluruhnya yang dijadikan sasaran adalah warga etnik keturunan Cina. Selang satu tahun berikutnya yaitu pada bulan Nopember 1999, terjadi aksi kerusuhan yang diikuti dengan tindakan pembakaran terhadap gedung Balai Kota Surakarta serta pengrusakan sarana dan fasilitas umum lainnya.

2. Kedua peristiwa kerusuhan tersebut mengindikasikan adanya tindakan kekerasan yang seolah-olah sudah menjadi perilaku umum atau budaya. Ironisnya, perilaku kekerasan tersebut banyak melibatkan para pemuda terutama pelajar.

3. Dilain pihak, aksi kekerasan tersebut memunculkan sebuah pertanyaan besar yaitu bagaimana mungkin kerusuhan bisa terjadi pada masyarakat yang memiliki kultur halus dengan nilai-nilai budaya Jawanya yang mementingkan prinsip kerukunan dan prinsip hormat melakukan tindakan anarkis, amoralasusila.

4. Visi Kota Surakarta sebagai kota budaya sekaligus kota pelajar hanya akan menjadi sebuah slogan tanpa makna, apabila tidak ada penanganan yang serius, terprogram, dan menyeluruh untuk mengatasi aksi kekerasan tersebut.

5. Untuk itu, pemerintah kota Surakarta bekerjasama dengan UNICEF melaksanakan suatu kebijakan berupa pelaksanaan 
"Kurikulum Pendidikan Budi Pekerti" dalam kurikulum sekolah di SMP Kota Surakarta. Kebijakan ini merupakan langkah preventif untuk mengatasi budaya kekerasan di Kota Surakarta.

6. Dalam pelaksanaannya materi Pendidikan Budi Pekerti merupakan cerminan dari nilai-nilai budaya Jawa. Hal ini bertujuan sebagai proses internalisasi dan pelestarian nilainilai budaya Jawa. Dalam proses pembelajarannya, selain aspek kognitif dan afektif, maka aspek psikomotorik atau perilaku harus dikondisikan sebagai suatu kebiasaan di lingkungan sekolah (implementasinya).

7. Diharapkan melalui langkahlangkah tersebut, yang dilakukan secara terprogram, berkesinambungan, terus menerus maka di masa-masa berikutnya tidak ada lagi peristiwa kerusuhan ke-12, ke-13 dan seterusnya terjadi di Kota Surakarta.

Deskripsi di atas menunjukkan bahwa untuk mengatasi budaya kekerasan di Kota Surakarta dengan cara menghidupkan kembali nilainilai budaya Jawa yang selama ini dianggap telah mulai pudar dan hilang dari masyarakat Jawa. Padahal nilai-nilai budaya Jawa ini secara akal dan logika, serta terbukti secara empiris dari fakta sejarah dapat mendatangkan kehidupan yang serasi, rukun tanpa perselisihan dan konflik. Inilah penerapan filsafat perenialisme secara operasional dalam bidang pendidikan.

\section{Penutup}

Perenialisme memandang bahwa kepercayaan-kepercayaan aksiomatis
Zaman Kuno dan Abad Pertengahan perlu dijadikan dasar penyusunan konsep filsafat dan pendidikan zaman sekarang. Hal ini berdasarkan keyakinan bahwa kepercayaankepercayaan tersebut berguna bagi abad sekarang.

Menurut perenialisme, realita tertinggi berada di balik alam yaitu Tuhan sendiri yang bersifat penuh kedamaian dan supernatural. Tuhan adalah aktualitas murni yang sunyi dan sepi dari substansi. Konsepkonsep dasar ontologi bersendikan atas pengertian-pengertian yang pasti. Seperti benda individual, esensi, aksiden, dan substansi. Pengetahuan dipandang mengandung kebenaran bila dapat memiliki evidensi- diri sendiri. Jalan yang perlu ditempuh akal untuk mencapainya adalah dengan penalaran, baik yang bersifat induktif, deduktif, serta perpaduan keduanya. Sedangkan nilai menurut perenialisme adalah pandangan mengenai hal-hal yang bersifat spiritual. Tuhan adalah sumber nilai dan karenanya nilai selalu bersifat teologis. Plato, Aristoteles dan Thomas Aquinas adalah tokoh-tokoh yang mempunyai pengaruh terhadap perkembangan konsep-konsep perenialisme.

Belajar menurut perenialisme adalah latihan mental dan disiplin jiwa. Pandangan tentang belajar hendaklah berdasarkan atas paham bahwa manusia itu pada hakikatnya rasionalistis. Sehingga belajar adalah mengembangkan berpikir logis, deduktif, dan induktif.

Agar belajar dapat berhasil sesuai dengan tujuannya maka harus dapat memenuhi kebutuhan umum 
manusia yang superlatif (bertaraf tinggi), dengan mengingat akan adanya saling pengaruh mempengaruhi antara belajar karena pengajaran dan belajar karena penemuan. Tugas pendidik adalah menuntun peserta didik kearah kematangan dengan menggunakan dasar-dasar di atas.

Bimbingan kearah kematangan dimulai di sekolah dasar yang berfungsi sebagai persiapan dan memberikan pengetahuan dan latihan dasar. Pendidikan menengah berfungsi untuk lebih meningkatkan peranan pendidikan dasar dengan meningkatkan program pendidikan umum. Program ini berisikan pelajaran-pelajaran kunci untuk memperkembangkan penalaran dan pengetahuan mengenai nilai-nilai utama sepanjang sejarah manusia. Pendidikan tinggi yang ideal adalah yang diselenggarakan mirip dengan perguruan tinggi yang terdapat pada Abad Pertengahan. Pendidikan dan semua kegiatan pendidikan tinggi bersendikan filsafat. Perguruan tinggi sekarang perlu menyelenggarakan penelitian sesuai dengan fungsinya masing-masing. Perlu dipahami bahwa penelitian yang bermutu tinggi adalah yang bersendikan pada filsafat. 


\section{Daftar Pustaka}

Abdul Aziz Wahab, dkk. 2009. Konsep Dasar IPS. Jakarta: Universitas Terbuka.

Barnadib, Imam. 1976. Filsafat Pendidikan : Sistem dan Metode. Yogyakarta : Andi Offset.

Drijarkara, S.J. 1964. Pertjikan Filsafat. Jakarta : PT Pembangunan.

Harun Hadiwijono. 1996. Sari Sejarah Filsafat 1. Yogyakarta : Kanisius. 1997. Sari Sejarah Filsafat 2. Yogyaakarta : Kanisius

Huxley, Aldous. 2001. Filsafat Perenialisme. Yogyakarta : Qolam.

Ornstein, Allan C \& Levine, Daniel U. 1985. An Introduction to the Foundations of Education. Boston : Houghton Mifflin Company.

Pelu, Musa. 2007. Implementasi NilaiNilai Budaya dalam Kurikulum Pendidikan Budi Pekerti di SMP Kota Surakarta (Studi Kasus tentang Upaya Pencegahan Budaya Kekerasan di Kota Surakarta). Laporan Penelitian Dana DIPA LPPM Universitas Sebelas Maret Surakarta. Surakarta:
Lembaga Penelitian dan Pengabdian Masyarakat (LPPM) Universitas Sebelas Maret Surakarta.

Redja Mudyahardjo. 2008. Filsafat Ilmu Pendidikan. Bandung : aremaja Rosdakarya.

Sri Agus. 2000. Sikap dan Perilaku Masyarakat Surakarta Pasca Kerusuhan Mei 1998. Surakarta : Fakultas Sastra Universitas Sebelas Maret.

Udin S. Winataputra, dkk. 2008. Materi dan pembelajaran IPS $S D$. Jakarta : Universitas Terbuka. 